\title{
Evidence of marine ice-cliff instability in Pine Island Bay from iceberg-keel plough marks
}

\author{
Matthew G. Wise ${ }^{1}$, Julian A. Dowdeswell ${ }^{1}$, Martin Jakobsson² \& Robert D. Larter ${ }^{3}$ \\ ${ }^{1}$ Scott Polar Research Institute, University of Cambridge, Lensfield Road, Cambridge CB2 1ER, UK. \\ ${ }^{2}$ Department of Geological Sciences and Bolin Centre for Climate Research, Stockholm University, 10691 Stockholm, Sweden. \\ ${ }^{3}$ British Antarctic Survey, Natural Environment Research Council, High Cross, Madingley Road, Cambridge CB3 0ET, UK.
}

Marine ice-cliff instability (MICI) processes could accelerate future retreat of the Antarctic Ice Sheet if ice shelves that buttress grounding lines more than 800 metres below sea level are lost ${ }^{1,2}$. The present-day grounding zones of the Pine Island and Thwaites glaciers in West Antarctica need to retreat only short distances before they reach extensive retrograde slopes ${ }^{3,4}$. When grounding zones of glaciers retreat onto such slopes, theoretical considerations and modelling results indicate that the retreat becomes unstable (marine ice-sheet instability) and thus accelerates $^{5}$. It is thought ${ }^{1,2}$ that MICI is triggered when retreat produces ice cliffs above the water line with heights approaching about 90 metres. However, observational evidence confirming the action of MICI has not previously been reported. Here we present observational evidence that rapid deglacial ice-sheet retreat into Pine Island Bay proceeded in a similar manner to that simulated in a recent modelling study ${ }^{1}$, driven by MICI. Iceberg-keel plough marks on the sea-floor provide geological evidence of past and present iceberg morphology, keel depth $^{6}$ and drift direction ${ }^{7}$. From the planform shape and cross-sectional morphologies of iceberg-keel plough marks, we find that iceberg calving during the last deglaciation was not characterized by small numbers of large, tabular icebergs as is observed today ${ }^{8,9}$, which would produce wide, flat-based plough marks ${ }^{10}$ or toothcomb-like multi-keeled plough marks ${ }^{11,12}$. Instead, it was characterized by large numbers of smaller icebergs with $\mathrm{V}$-shaped keels. Geological evidence of the form and water-depth distribution of the plough marks indicates calving-margin thicknesses equivalent to the threshold that is predicted to trigger ice-cliff structural collapse as a result of $\mathrm{MICI}^{13}$. We infer rapid and sustained ice-sheet retreat driven by MICI, commencing around 12,300 years ago and terminating before about 11,200 years ago, which produced large numbers of icebergs smaller than the typical tabular icebergs produced today. Our findings demonstrate the effective operation of MICI in the past, and highlight its potential contribution to accelerated future retreat of the Antarctic Ice Sheet.

Since 1994, the floating extensions of Pine Island and Thwaites glaciers have thinned by $\sim 18 \%{ }^{14}$, attributed mainly to enhanced basal melt induced by the influx of warm, Circumpolar Deep Water 
into the sub-ice-shelf cavities since the mid-twentieth century ${ }^{14-16}$. The reduced buttressing effect on up-glacier ice has resulted in accelerated seaward ice flow, glacier thinning and grounding-zone retreat ${ }^{17}$. Today, Pine Island and Thwaites glaciers ground on ridges at the downstream ends of extensive retrograde beds, far below sea-level ${ }^{4,14}$, raising the possibility that any further landward retreat of the grounding-zone could trigger runaway MISI ${ }^{2,18}$. Recent studies suggest that such runaway retreat could be compounded by MICI processes $^{1,2}$.

When an ice grounding zone retreats onto a bed deep enough for calving to produce marineterminating ice cliffs with total height approaching $1 \mathrm{~km}$ (with >90 m elevation above sea level), unopposed longitudinal stresses in the ice margin have the potential to exceed the yield strength of ice $(\sim 1 \mathrm{MPa})^{1,2,13}$. This ice cliff geometry implies a grounding line at $>800 \mathrm{~m}$ below sea level. In this situation, the stresses are expected to promote accelerated calving, which on a retrograde bed leads to the exposure of an even higher ice cliff; hence, a runaway calving cycle, or MICI, could be initiated $^{1,2,13}$. The increased frequency of calving is expected to produce a large number of relatively small icebergs in contrast to the small number of large, tabular icebergs that are typical of the present regime ${ }^{8,9}$. Such runaway calving will be accelerated further if summer temperatures become warm enough to produce sufficient meltwater to fill crevasses, inducing hydro-fracture and potentially causing complete ice-shelf collapse into a large number of 'small' icebergs, as observed on the Larsen B Ice Shelf in $2002^{19}$. Mechanical failure of an ice-cliff through MICI would result in rapid grounding-line retreat, until a re-stabilising point was reached by retreat of the grounding zone onto a topographic high, too shallow to permit floating ice cliffs exceeding the critical thickness ${ }^{1,2,20}$. Moreover, MICI implies the removal of the up-glacier buttressing forces exerted by the marine components of each glacier, thereby increasing grounding-line ice-fluxes ${ }^{1,2}$. Incorporating MICI into numerical ice sheet-ice shelf models, in addition to MISI, results in predicted West Antarctic Ice Sheet retreat an order of magnitude faster (up to $3 \mathrm{~m}$ contribution to global sea-level rise within 100 years $\left.{ }^{1}\right)$ than other recent studies $\left(\sim 0.1\right.$ to $0.6 \mathrm{~m}$ by $\left.2100 \mathrm{AD}^{3,21}\right)$.

Grounding-zone retreat from the Amundsen Sea continental shelf through Pine Island Trough since the onset of deglaciation ( $18 \mathrm{ka} \mathrm{BP})$ crossed basins $>1,500 \mathrm{~m}$ below modern sea level ${ }^{22}$. Here, we present seafloor geological evidence from the mapping and analysis of iceberg-keel plough marks within the mid-shelf area of Pine Island Trough and its adjacent banks using multibeam bathymetry data (Methods; Fig. 1a-d). This analysis indicates the calving of many relatively small icebergs, and an absence of large tabular icebergs, during ice retreat from a large grounding-zone wedge (GZW; Fig. 1a,f) in this region between 12.3 - $11.2 \mathrm{cal}$. ka BP ${ }^{22}$. We use a simple manual 
mapping technique to identify the location and modern-water depth of iceberg-keel plough marks (Figs. 1e-f, Extended Data Figure 1) and cross-sectional profiles to quantify iceberg cross-sectional morphology (Methods) and keel-type (Fig. 2).

We find that iceberg-keel plough marks are widespread across the study area, identifying 10,831 individual features (Figs. 1a-c, Extended Data Figure 1) over a modern water depth range of 507$848 \mathrm{~m}$ (Fig. 1e-f). The majority of plough marks ( $\mathrm{n}=10,745)$ are single-keeled in form (Fig. 2a-b, e), and present relatively small measured widths and incision depths (Fig. 2g), averaging $115 \mathrm{~m}$ and 2.8 $\mathrm{m}$, respectively. This is despite a large range of widths $(12-449 \mathrm{~m})$ and incision depths $(<0.1$ to 22.0 m) being recorded (Fig. 2g). Cross-sectional analysis, calculating comparably small mean (38.9) and median (34.4) width/depth ratios, and a normalised frequency distribution (Fig. 2h), confirm a typically small iceberg-keel plough mark size that is associated with a predominantly v-shaped cross-sectional morphology (Fig. 2a-b,e). The ploughing iceberg keels were therefore likely to be relatively small in size and relatively 'pinnacled' in shape.

Today, Pine Island and Thwaites glaciers characteristically calve large, tabular icebergs, with approximately flat topsides (Figs. 3a,b) ${ }^{8,9}$. Underside morphologies, whilst seldom observed directly, most likey reflect the highly irregular and rugged basal morphology of Pine Island ice shelf, as visualised by IceBridge Airborne Topographic Mapper (Fig. 3b, Extended Data Figure 3), and Autosub derived, upward directed, multibeam echosounder ${ }^{23}$ datasets.

Thus, grounded tabular icebergs are expected to produce wide, flat-based iceberg-keel plough marks (e.g. Hambergbukta, Spitsbergen ${ }^{10}$ ), or exactly parallel multi-keeled plough marks with prevalent 'toothcomb-like' morphologies (Fig. 2d,f) (e.g. M'Clure Strait, Canadian Arctic ${ }^{11}$; Argentine margin $^{12}$ ), if iceberg drift is perpendicular or parallel, respecitively, to the underside channel-ridge systems (Extended Data Figure 4). In Pine Island Bay, no iceberg-keel plough marks present wide, flat-based morphologies and, whilst we do observe 86 multi-keeled plough marks, these are limited in number $(<1 \%$ of the total observed), comprise no more than two parallel incisions per feature, and are no more than $444 \mathrm{~m}$ wide. By contrast, multi-keeled iceberg plough marks with 'toothcomb-like' morphologies, observed previously on the Argentine margin north of the Falkland Islands ${ }^{12}$ and in M'Clure Strait, Canadian Arctic ${ }^{11}$, imply the grounding of icebergs with basal widths of $\sim 2 \mathrm{~km}$ and $\sim 2.7 \mathrm{~km}$, respectively. Thus, a tabular iceberg genesis for Pine Island Bay plough marks is not supported. 
We observe iceberg-keel plough marks to a maximum modern water depth of $848 \mathrm{~m}$ (Fig. 1e-f), implying the existence of icebergs at least $949 \mathrm{~m}$ in thickness, assuming floatation at hydrostatic equilibrium (density of sea water $=1,027 \mathrm{~kg} \mathrm{~m}^{-3}$, density of ice $=917 \mathrm{~kg} \mathrm{~m}^{-3}$ ), and no change in relative sea-level (RSL) since the time of ploughing. If it is assumed that these icebergs calved from an ice-shelf margin of equal thickness, the calving face would have had a total thickness of $949 \mathrm{~m}$, including a cliff rising to $\sim 101 \mathrm{~m}$ above sea level. Assuming crevasse penetration to $50 \%$ of the total ice thickness (considering basal and surface crevasses together under standard glaciological conditions and stresses ${ }^{13}$ ), the theoretical critical subaerial cliff elevation for ice $949 \mathrm{~m}$ in thickness would be $\sim 101 \mathrm{~m}^{13}$. However, by considering hydro-fracture and additional mechanics from highorder bending stresses and fracture mechanics, not accounted for here, substantially deeper crevasse penetration would be plausible, thereby reducing the critical subaerial cliff elevation further ${ }^{2,13}$. Thus, even under the simple consideration we make here, MICI-driven iceberg calving would occur. We note that if the depth of iceberg-keel penetration into the seafloor sediments is considered in addition, the total iceberg-keel depth will be greater than presented here.

Whilst being poorly constrained, modelled decreases in Holocene RSL within Pine Island Bay (at most $60 \mathrm{~m}, \sim 8 \mathrm{cal} . \mathrm{ka} \mathrm{BP}^{24}$ ), resulting from isostatic rebound following ice retreat from the Amundsen Sea continental shelf ${ }^{24}$, imply iceberg-keel depths larger than those calculated here - our keel-depth calculations are therefore conservative. By factoring a maximum $60 \mathrm{~m}$ RSL decrease into our calculations, subaerial ice-cliffs up to $\sim 109 \mathrm{~m}$ in elevation are implied. We note that the limited change in subaerial ice-cliff elevation $(\sim 8 \mathrm{~m})$ in spite of a $60 \mathrm{~m}$ change in RSL is the result of an iceberg floating hydrostatically, whereby about $90 \%$ of its mass (and thereby total thickness), is submerged below the ambient sea-level.

To promote stability and prevent rotation to a more stable orientation, drifting icebergs floating hydrostatically must be wider than they are high, with aspect ratios exceeding a critical value (see Methods; Extended Data Figure 5). For the deepest ploughing icebergs, with drafts up to $848 \mathrm{~m}$ depth (Fig. 1e), we calculate that minimum waterline widths of as little as $712 \mathrm{~m}$ would favour metastablility (Methods).

As we observe the deepest plough marks on retrograde beds, any grounding-line retreat into deeper water associated with MICI is expected to be rapid and, probably, runaway in nature ${ }^{1,2}$. This is consistent with published ice-retreat chronologies that do not place a limit on the maximum possible rate of grounding-zone retreat ${ }^{22}$ (Fig. 4). However, because Pine Island and Thwaites 
glaciers are present today and buttressed by floating ice shelves ${ }^{9}$, re-stabilisation and the termination of runaway MICI must have occurred at some time prior to the onset of contemporary retreat. This was most likely driven by grounding-line retreat onto the surface of a prominent, across-trough bathymetric ridge, located $\sim 108 \mathrm{~km}$ from the Bedmap2-defined calving line ${ }^{22,25}$ (Fig. 4, Extended Data Figure 2). Despite being cut through by deep channels, some reaching water depths $>1,000 \mathrm{~m}$ (Extended Data Figure 2), ice thicknesses exceeding 642 m (Extended Data Figure 2) would be grounded along most of the ridge, and thus allow the ice margin to stabilise at a total thickness lower than the threshold for $\mathrm{MICI}^{1}$ (Fig. 4). Any atmospheric cooling, reducing the volume of surface water and, therefore, hydro-fracture induced calving, if occurring, would enhance this restabilisation further. Low melt rates and an absence of discernible surface water pools on the modern Pine Island Glacier, together with evidence of a subsequent rapid, early Holocene retreat $\sim 8,000$ years ago ${ }^{26}$ followed by a period of stabilisation offshore of the modern Pine Island Glacier grounding-line, support our interpretation.

Although Pine Island Glacier today calves icebergs with keels up to $633 \mathrm{~m}$ deep ${ }^{27}$ (Fig. 1e), such bergs are unlikely to reach the study area until their draft reduces enough to pass over a prominent bathymetric ridge, for the most part $<600 \mathrm{~m}$ in depth, located $\sim 108 \mathrm{~km}$ seaward of the Bedmap2defined calving margin 22,25 (Extended Data Figure 2). Furthermore, a similar level of morphological preservation, or freshness of appearance, for plough marks above and below $\sim 600 \mathrm{~m}$, suggests that the majority of features are of a similar age and, thus, relict.

However, our observations with respect to published deglacial chrologies ${ }^{22}$ imply two periods of iceberg ploughing. First, we observe exceptionally long iceberg-keel plough marks (up to 11,700 m length), a number of which contain 'corrugation ridges ${ }^{28}$, at water depths $>700 \mathrm{~m}$, seaward of a large GZW (Extended Data Figure 1). These plough marks record widths and incision depths of 66 to $444 \mathrm{~m}$, and 1.7 to $19.6 \mathrm{~m}$, respectively. Icebergs calved after the GZW was formed could only drift further offshore than the wedge crest $(\sim 670 \mathrm{~m})$ if they possessed shallower drafts. Moreover, deepkeeled icebergs drifting onshore would not be able to pass over the shallow continental-shelf edge $(\sim 550 \mathrm{~m})$ and, therefore, could not have formed the observed plough marks. In addition, the relatively shallow banks either side of Pine Island Trough (Fig. 1a) would act to channel and steer deep-drafted icebergs seaward as illustrated by offshore-aligned directional orientations (Fig. 1h), and would prevent the drift of such icebergs laterally into the trough. These plough marks must, therefore, predate GZW formation, implying an 'early' calving event as inferred by Ref. 28. This is substantiated by the partial overlay of GZW sedimentary material on top of a number of plough 
marks and mega-scale glacial lineations located seaward of the depocentre. The remaining plough marks deeper than $\sim 670 \mathrm{~m}$ depth located on the inshore side of the GZW, and those overlaying the GZW itself, must therefore post-date ice retreat from the GZW, at $\sim 12.3 \mathrm{cal}$. ka BP 22 . They imply a second, later, calving event. By $\sim 11.2 \mathrm{cal}$. $\mathrm{ka} \mathrm{BP}^{22}$, the grounding zone had retreated $>200 \mathrm{~km}$ into inner Pine Island Bay, indicating relatively rapid ice retreat from the GZW. We note that throughout the Holocene, warm water (Circumpolar Deep Water) inflow onto the Amundsen Sea continental shelf has been the main driver of ice retreat throughout the region ${ }^{16}$. Significantly, an early Holocene phase of warm water inflow (at least $10.4-7.5 \mathrm{ka} \mathrm{BP}$ ) had likely started before 12.0 $\mathrm{ka} \mathrm{BP}$, which is around the time of the later calving event identified here ${ }^{16}$.

We observe an absence of widespread parallelism between adjacent plough mark features (Fig. 1gh), which supports formation under an at least seasonally open-ocean environment, rather than one dominated by thick perennial sea-ice cover or ice mélange, which would restrict iceberg drift and plough mark orientation to a single, uniform direction ${ }^{29}$. We therefore propose a period of icebergkeel plough mark formation under climatic conditions relatively similar to today with little or no surface meltwater availability. Under significantly warmer conditions, such as those that may have pertained during the early Holocene climate optimum $(\sim 11-9.5 \mathrm{cal} \text {. ka BP })^{30}$, hydro-fracture and mechanical forcing from the infilling of crevasses by surface melt and rainfall would likely increase the frequency of iceberg calving events by vertically extending crevasses (basal and surface) to a critical thickness ${ }^{2}$. Moreover, where this occurs in immediate proximity to the grounding line, the ice column will be weakened from a reduction in backstress ${ }^{1,2}$. Hydrofracture can therefore act as a trigger, and an accelerator, of MICI-driven retreat ${ }^{1,2}$. Significantly, we observe iceberg-keel plough mark formation prior to the warm conditions of the early Holocene climate optimum. We therefore propose the effective operation of MICI-driven retreat in the absence of extensive surface melting during ice retreat since the LGM.

Our findings provide observational evidence of rapid deglacial retreat of the Pine Island-Thwaites ice stream from the crest of a large, mid-shelf GZW to a location $\sim 108 \mathrm{~km}$ offshore of the Bedmap2defined calving line, commencing $\sim 12.3 \mathrm{cal}$. ka BP. The consequent removal of induced buttressing stresses enabled significant and rapid grounding-line retreat and iceberg calving by MICI processes, prior to grounding-zone re-stabilisation on a prominent bathymetric ridge (Fig. 4). We provide the first physical evidence for such a process having occurred in the past, and emphasise its effective operation in the absence of extensive surface melting and hydro-fracture induced calving. We conclude that such processes are unlikely to be confined to the past, given the retrograde bed slopes 
which the retreating grounding zones of the modern Pine Island and Thwaites glaciers are approaching, and the absence of discernible stabilisation features (e.g. bedrock rises) upstream of the modern grounding-zone ${ }^{3,4}$. Thus, we conclude that MICI has the potential to contribute significantly to accelerated future retreat of ice under contemporary warming climatic conditions, as predicted by new modelling studies which suggest enhanced rates of sea-level rise over the coming century under most likely emissions scenarios ${ }^{1,2}$, and emphasise the importance of its inclusion in future numerical ice shelf-ice sheet models.

\section{References.}

1. Pollard, D., DeConto, R. M. \& Alley, R. B. Potential Antarctic Ice Sheet retreat driven by hydrofracturing and ice cliff failure. Earth Planet. Sci. Lett. 412, 112-121 (2015).

2. DeConto, R. M. \& Pollard, D. Contribution of Antarctica to past and future sea-level rise. Nature 531, 591-597 (2016)

3. Joughin, I., Smith, B. E. \& Medley, B. Marine Ice Sheet Collapse Potentially Underway for the Thwaites Glacier Basin, West Antarctica. Science 18-19 (2014). doi:10.1126/science.1249055

4. Rignot, E., Mouginot, J., Morlighem, M., Seroussi, H. \& Scheuchl, B. Widespread, rapid grounding line retreat of Pine Island, Thwaites, Smith, and Kohler glaciers, West Antarctica, from 1992 to 2011. Geophys. Res. Lett. 41, 3502-3509 (2014).

5. Gudmundsson, G. H., Krug, J., Durand, G., Favier, L. \& Gagliardini, O. The stability of grounding lines on retrograde slopes. Cryosph. 6, 1497-1505 (2012).

6. Goff, J. A. \& Austin, J. A. Seismic and bathymetric evidence for four different episodes of iceberg scouring on the New Jersey outer shelf: Possible correlation to Heinrich events. Mar. Geol. 266, 244-254 (2009).

7. Todd, B. J., Lewis, C. F. M. \& Ryall, P. J. C. Comparison of trends of iceberg scour marks with iceberg trajectories and evidence of paleocurrent trends on Saglek Bank, northern Labrador Shelf. Can. J. Earth Sci. 25, 1374-1383 (1988).

8. Rignot, E. Ice-shelf changes in Pine Island Bay, Antarctica, 1947-2000. J. Glaciol. 48, 247-256 (2002).

9. MacGregor, J. A., Catania, G. A., Markowski, M. S. \& Andrews, A. G. Widespread rifting and retreat of iceshelf margins in the eastern Amundsen Sea Embayment between 1972 and 2011. J. Glaciol. 58, 458-466 (2012).

10. Noormets, R., Kirchner, N., Flink, A. E. \& Dowdeswell, J. A. Possible iceberg-produced submarine terraces in Hambergbukta, Spitsbergen. Geol. Soc. London, Mem. 46, 101-102 (2016).

11. Batchelor, C. L., Dowdeswell, J. A., Dowdeswell, E. K. \& Todd, B. J. A subglacial landform assemblage on the outer-shelf of M'Clure Strait, Canadian Arctic, ploughed by deglacial iceberg keels. Geol. Soc. London, Mem. 46, 337-340 (2016).

12. López-Martínez, J., Muñoz, A., Dowdeswell, J. A., Linés, C. \& Acosta, J. Relict sea-floor ploughmarks record deep-keeled Antarctic icebergs to $45^{\circ} \mathrm{S}$ on the Argentine margin. Mar. Geol. 288, 43-48 (2011).

13. Bassis, J. N. \& Walker, C. C. Upper and lower limits on the stability of calving glaciers from the yield strength envelope of ice. Proc. R. Soc. A Math. Phys. Eng. Sci. 468, 913-931 (2012).

14. Paolo, F. S., Fricker, H. A. \& Padman, L. Volume loss from Antarctic ice shelves is accelerating. Science 348, 327-331 (2015).

15. Smith, J. A. et al. Twentieth-century retreat of Pine Island Glacier. Nature 541, 77-80 (2017).

16. Hillenbrand, C.-D. et al. West Antarctic Ice Sheet retreat driven by Holocene warm water incursions. Nature 547, 43-48 (2017).

17. Rignot, E. Changes in West Antarctic ice stream dynamics observed with ALOS PALSAR data. Geophys. Res. Lett. 35, doi:10.1029/2008GL033365 (2008).

18. Favier, L. et al. Retreat of Pine Island Glacier controlled by marine ice-sheet instability. Nat. Clim. Chang. 5, 15 (2014).

19. Banwell, A. F., MacAyeal, D. R. \& Sergienko, O. V. Breakup of the Larsen B Ice Shelf triggered by chain reaction drainage of supraglacial lakes. Geophys. Res. Lett. 40, 5872-5876 (2013).

20. Pfeffer, W. T., Harper, J. T. \& O’Neel, S. Kinematic Constraints on Glacier Contributions to 21st-Century SeaLevel Rise. Science. 321, 1340-1343 (2008).

21. Levermann, A. et al. Projecting Antarctic ice discharge using response functions from SeaRISE ice-sheet models. Earth Syst. Dyn. 5, 271-293 (2014).

22. Larter, R. D. et al. Reconstruction of changes in the Amundsen Sea and Bellingshausen Sea sector of the West 
Antarctic Ice Sheet since the Last Glacial Maximum. Quat. Sci. Rev. 100, 55-86 (2014).

23. Dutrieux, P. et al. Basal terraces on melting ice shelves. Geophys. Res. Lett. 41, 5506-5513 (2014).

24. Whitehouse, P. L., Bentley, M. J., Milne, G. A., King, M. A. \& Thomas, I. D. A new glacial isostatic adjustment model for Antarctica: calibrated and tested using observations of relative sea-level change and present-day uplift rates. Geophys. J. Int. 190, 1464-1482 (2012).

25. Graham, A. G. C. et al. Submarine glacial-landform distributions across the West Antarctic margin, from grounding line to slope: the Pine Island-Thwaites ice stream system. Geol. Soc. London, Mem. 46, 493-500 (2016).

26. Johnson, J. S. et al. Rapid thinning of Pine Island Glacier in the early Holocene. Science 343, 999-1001 (2014).

27. Dowdeswell, J. A. \& Bamber, J. L. Keel depths of modern Antarctic icebergs and implications for sea-floor scouring in the geological record. Mar. Geol. 243, 120-131 (2007).

28. Jakobsson, M. et al. Geological record of ice shelf break-up and grounding line retreat, Pine Island Bay, West Antarctica. Geology 39, 691-694 (2011).

29. Kristoffersen, Y. et al. Seabed erosion on the Lomonosov Ridge, central Arctic Ocean: A tale of deep draft icebergs in the Eurasia Basin and the influence of Atlantic water inflow on iceberg motion? Paleoceanography 19, doi:10.1029/2003PA000985 (2004).

30. Bentley, M. J. et al. Mechanisms of Holocene palaeoenvironmental change in the Antarctic Peninsula region. The Holocene 19, 51-69 (2009).

31. Scambos T., Bohlander, J. And Raup, B. Images of Antarctic Ice Shelves $\left(7^{\text {th }}\right.$ Noveber 2009,3 and 18 November 2013). National Snow and Ice Data Centre http://dx.doi.org/10.7265/N5NC5Z4N.

Acknowledgements M.G.W. is funded by a UK Natural Environment Research Council (NERC) PhD studentship (LCAG/247 RG72013) held at the Scott Polar Research Institute, University of Cambridge. The OSO0910 expedition with Swedish icebreaker Oden was carried out as collaboration between the Swedish Polar Research Secretariat, the Swedish Research Council, and the US National Science Foundation (NSF). Part of the data shown in Extended Data Fig. 2 were collected on UK NERC-funded cruise JR179.

Author Contributions J.A.D. and R.D.L. conceived the idea for the study. M.G.W. made the measurements on the multibeam bathymetry data and analysed the results. M.J. was responsible for collection and processing of the IB/RB Oden multibeam bathymetry data. M.G.W. wrote the initial manuscript and all co-authors commented and provided input to drafts and the final version.

Author Information Reprints and permissions information is available at www.nature.com/reprints. The authors declare no competing financial interests. Readers are welcome to comment on the online version of the paper. Publisher's note: Springer Nature remains neutral with regard to jurisdictional claims in published maps and institutional affiliations. Correspondence and requests for materials should be addressed to J.A.D. (jd16@cam.ac.uk) or M.G.W. (mgw37@cam.ac.uk). 

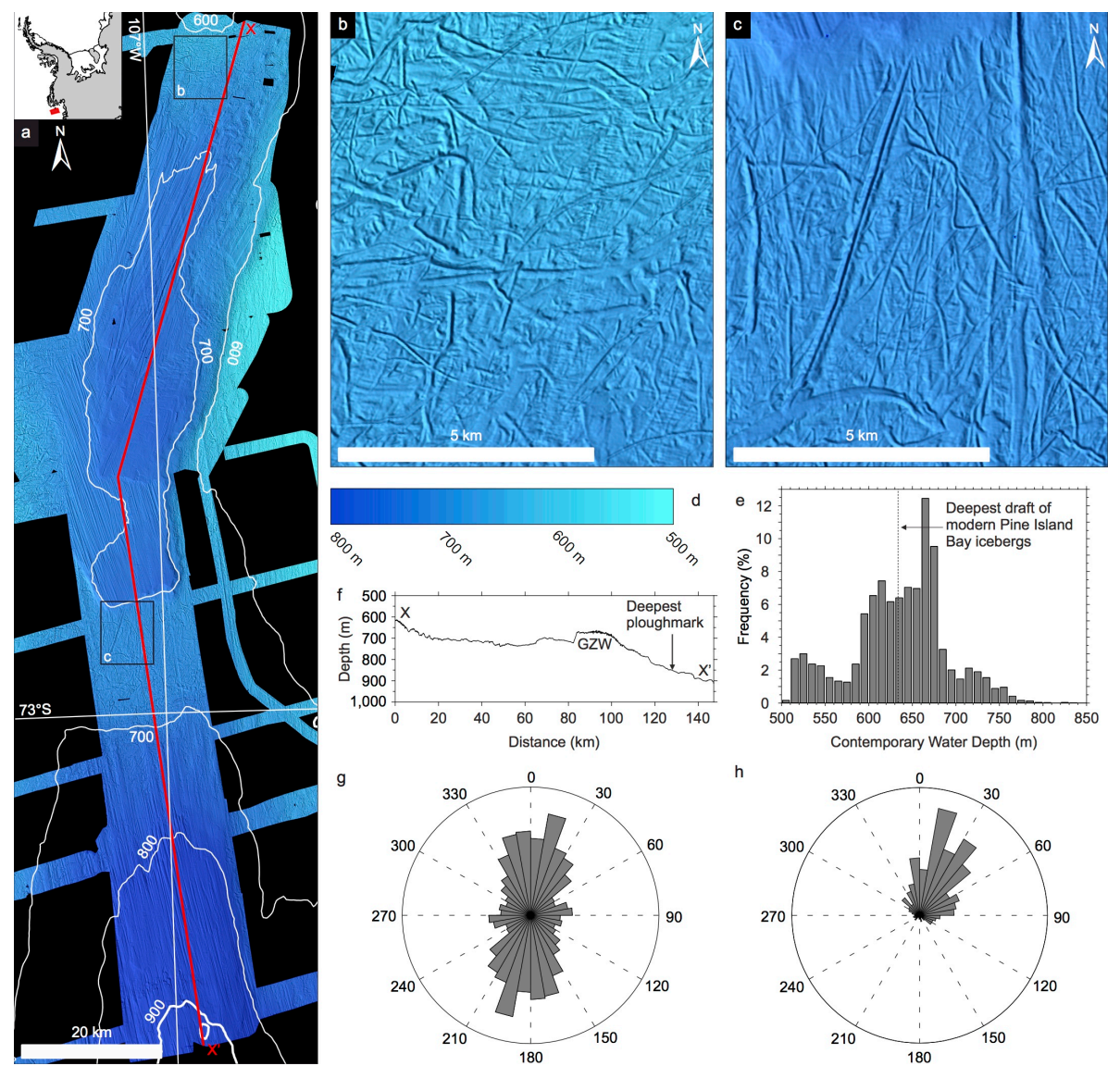

Figure 1: Distribution and orientation of iceberg-keel ploughmarks within Pine Island Trough. Bathymetry of the mid-shelf Pine Island Trough (PIT) (acquisition system Kongsberg EM122, frequency $12 \mathrm{kHz}$, grid-cell size $20 \mathrm{~m}$ ) (a), highlighting regions of extensive iceberg-keel ploughing at the seaward extent of the study area (b), and on the surface of the large grounding-zone wedge (c). The colour palette of water depths for these panels is shown in d. 10,831 iceberg-keel ploughmarks are observed (Extended Data Figure 1) over a multi-modal modern water-depth distribution (e). The location of the deepest iceberg-keel ploughmark $(848 \mathrm{~m})$ with respect to the long-axis bathymetric profile of Pine Island Trough, $\mathbf{x}-\mathbf{x}^{\prime}$, is shown in $\mathbf{f}$. The orientation of iceberg-keel ploughmarks, assuming iceberg drift is bi-directional along the length of all ploughmarks (g), and where drift is confined to a single direction (h) when iceberg plough-ridges or grounding-pits are observed for 649 ploughmarks. 

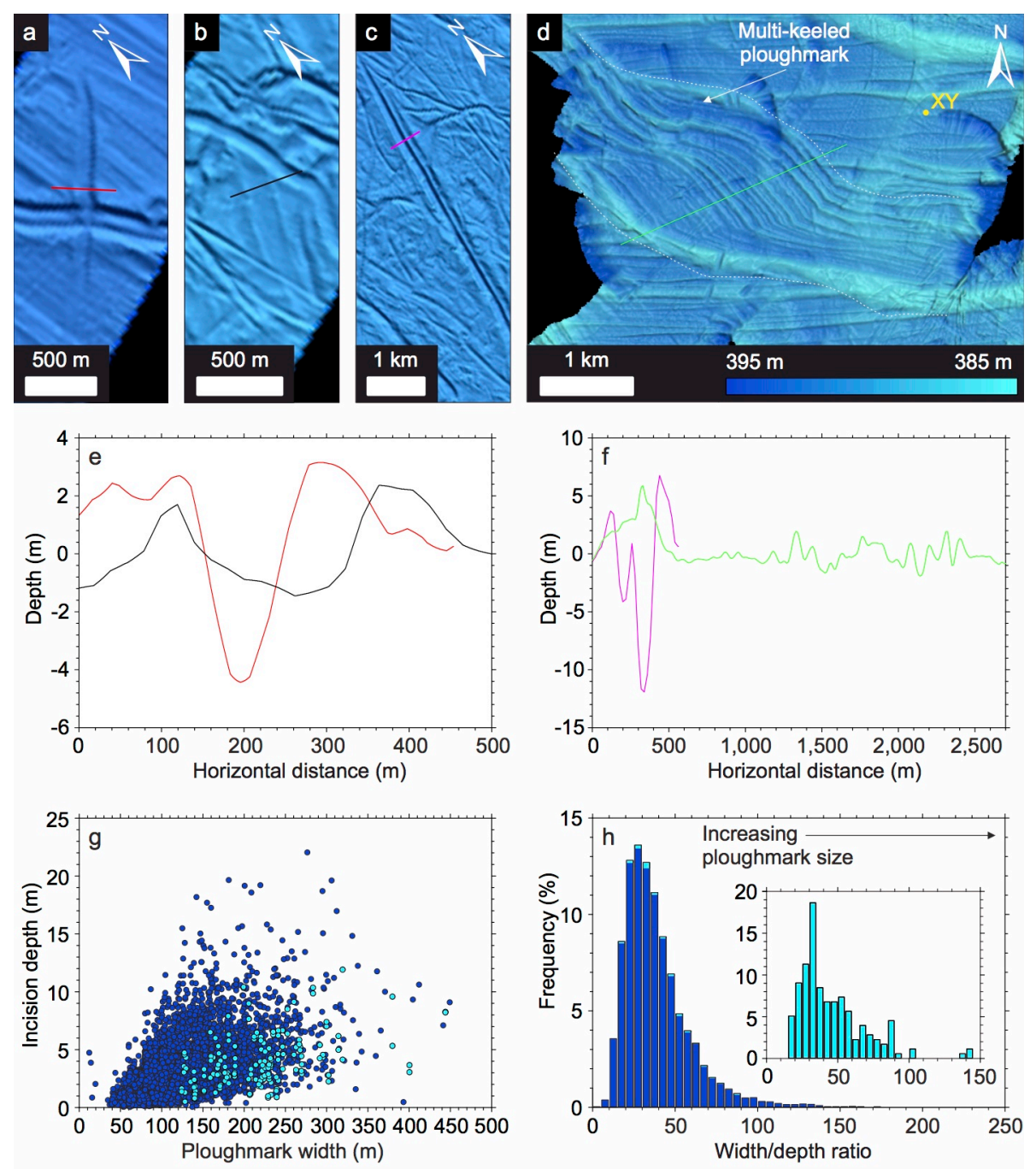

Figure 2: Iceberg-keel ploughmark cross-sectional shape, size and keel-type. Shaded-relief examples of typical single$(\mathbf{a}, \mathbf{b})$, and multi-keeled (c) ploughmarks observed in Pine Island Trough. The location of each ploughmark within the study area is shown in Extended Data Figure 1. d, Example of a 'toothcomb-like' multi-keeled ploughmark observed in M'Clure Strait, Canadian Arctic, formed by a large, tabular iceberg, with an irregular underside ${ }^{11}$. Point XY is located at $128^{\circ} 36^{\prime} 47^{\prime \prime} \mathrm{W}, 74^{\circ} 48^{\prime} 55^{\prime \prime} \mathrm{N}$. e, Cross-sectional profiles at locations marked in a and b, illustrate v- and u-shaped ploughmarks, respectively. f, A comparison of the cross-sections of multi-keeled ploughmarks $\mathbf{c}$ and $\mathbf{d}$. g, Comparison of the measured width and incision depth of all observed iceberg-keel ploughmarks. Single- and multi-keeled ploughmarks are shown in dark blue and light blue, respectively. h, Histogram of all iceberg-keel ploughmark width/depth ratios, with the frequency of single- and multi-keeled ploughmarks shown in dark blue and light, respectively. Inset, frequency distribution (\%) of multi-keeled iceberg ploughmark width/depth ratios. The majority of features observed are relatively narrow in relation to their incision depth, and single-keeled in form. 

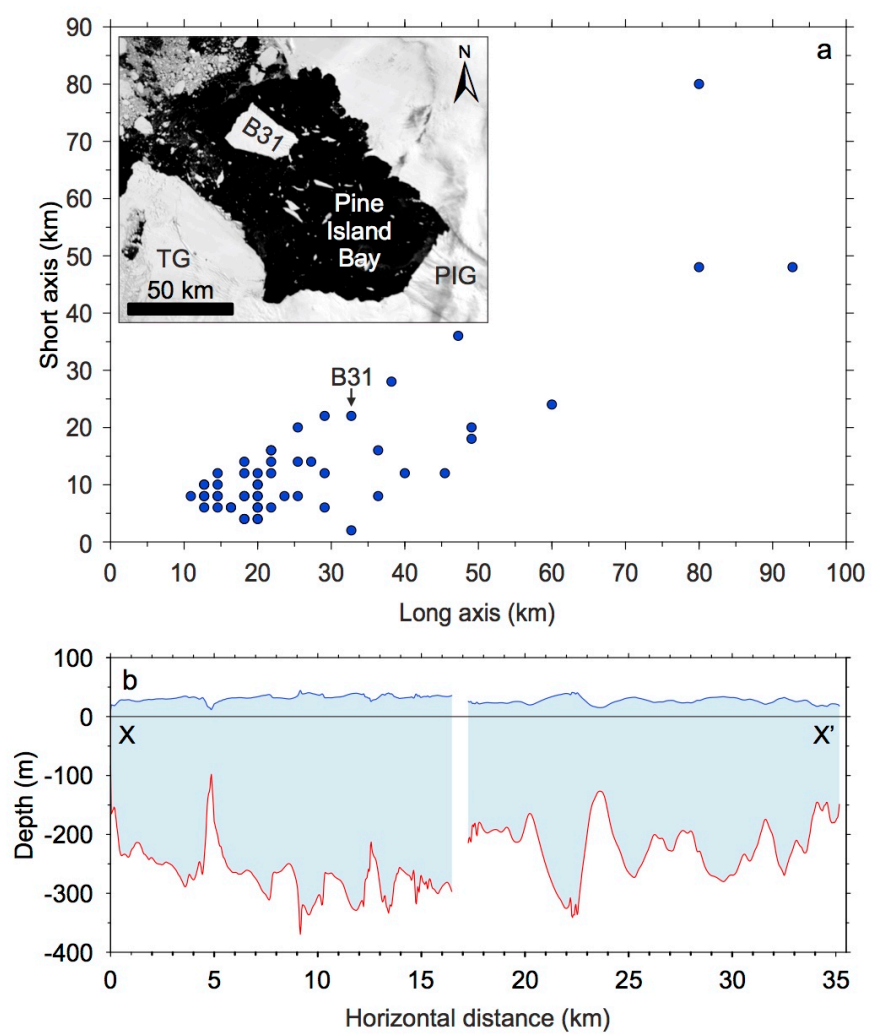

Figure 3: Dimensions of modern tabular icebergs in Pine Island Bay. a, The measured long and short axes of tabular icebergs tracked by the U.S. National Ice Centre (NIC) on $17^{\text {th }}$ June 2016, extracted from a circum-Antarctic database of current positions. Inset, NASA MODIS image of iceberg B31 from the National Snow and Ice Data Centre (NSIDC) ${ }^{31}$ (from 24 ${ }^{\text {th }}$ December 2013; https://nsidc.org/data/iceshelves_images/index_modis.html), illustrating the tabular planform shape of icebergs that typically calve from the modern Pine Island and Thwaites glaciers. $\mathbf{b}$, IceBridge (www.nasa.gov/mission_pages/icebridge) radar profile (blue curve) of the Pine Island ice shelf from flight DC8-100124 ( $7^{\text {th }}$ November 2009) along transect X-X' of Extended Data Figure 3, illustrating the highly rugged basal profile (red curve), assuming floatation under hydrostatic conditions (meteoric ice and seawater densities of $917 \mathrm{~kg} \mathrm{~m}^{-3}$ and $1,027 \mathrm{~kg}$ $\mathrm{m}^{-3}$, respectively). 


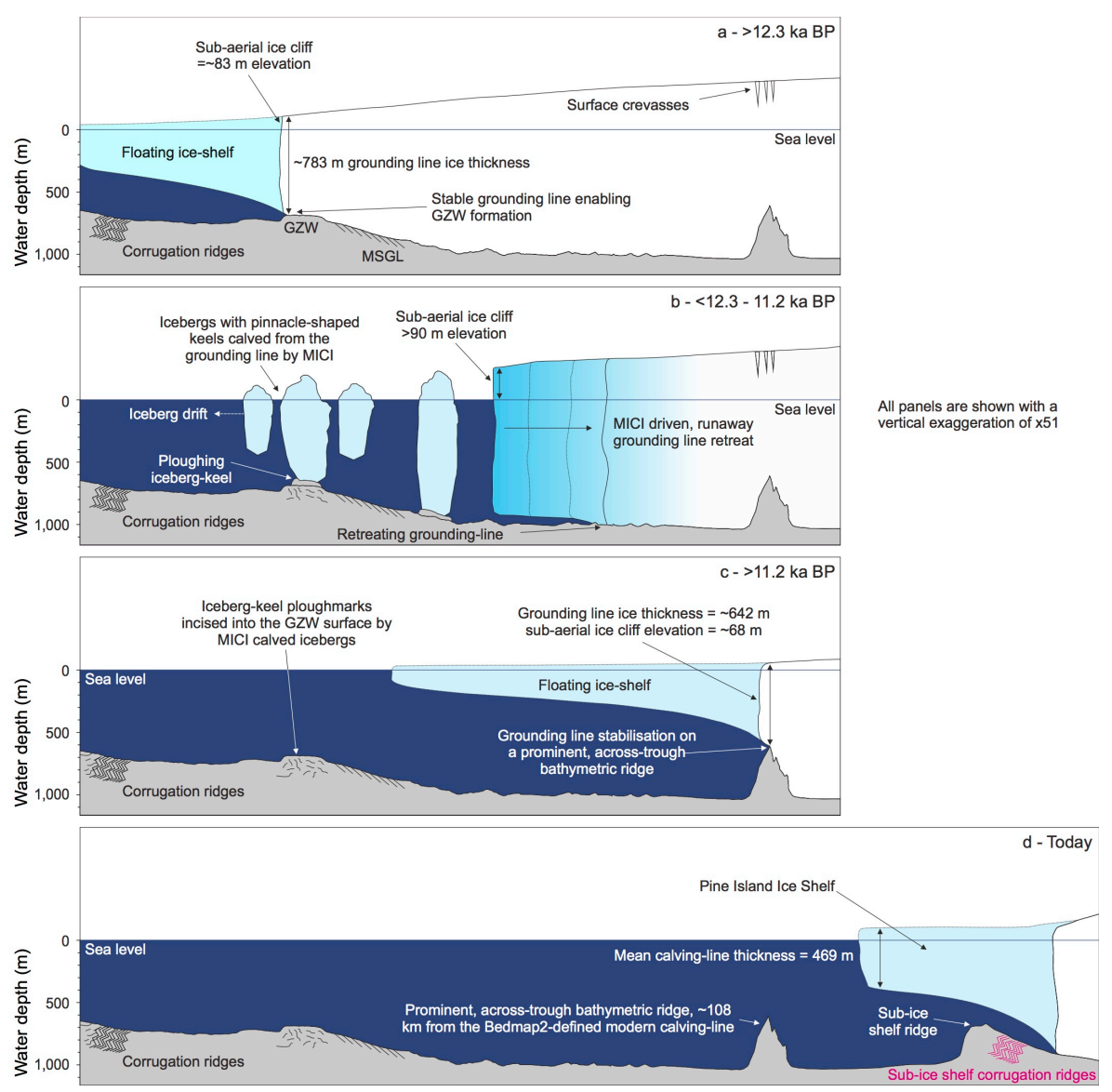

Figure 4: Conceptual sketches of MICI-driven, runaway grounding-line retreat in Pine Island Trough. a, illustrates a period of grounding-line stability on the apex of a large GZW prior to ice retreat $\sim 12.3 \mathrm{cal}$. ka $\mathrm{BP}^{22}$. $\mathbf{b}$, following unpinning from the GZW by $12.3 \mathrm{cal}$. $\mathrm{ka} \mathrm{BP}^{22}$, grounding-line retreat into deeper water results in the exposure of greater grounding-line ice thicknesses $(>1 \mathrm{~km})$ and subaerial cliff elevations $\sim 90 \mathrm{~m}^{1,2,13}$. Longitudinal stresses, exceeding the yield strength of ice, result in the accelerated calving of icebergs with pinnacle-shaped keels ${ }^{1,2,13}$. Driving the grounding line inland and exposing higher subaerial ice cliff elevations, a runaway calving cycle through MICIprocesses is initiated $^{1,2}$. c, MICI drives the grounding line inland until a re-stabilisation point is reached at a prominent, across-trough bathymetric ridge acting as pinning point. Being too shallow to support tall unstable ice cliffs, MICI is terminated before $\sim 11.2 \mathrm{cal}$. ka BP 22 . $\mathbf{d}$, the modern situation of Pine Island Glacier, illustrating the approximate location of the modern Pine Island calving-line and a prominent sub-ice shelf ridge, upon which 'corrugation ridges' are observed $^{25}$. In all parts, black-coloured corrugation ridges show the location of corrugation ridges formed during an earlier period of collapse ${ }^{28}$, prior to re-stabilisation of the grounding line. A second set of corrugation ridges, observed on the seafloor beneath the modern Pine Island ice shelf in panel d, are coloured pink. All panels are shown with a vertical scale exaggerated 51 times relative to the horizontal scale. 


\section{Methods}

We used pre-gridded multi-beam swath-bathymetry covering $4,140 \mathrm{~km}^{2}$ of the mid-shelf Pine Island Trough and adjacent banks, acquired originally during cruise OSO0910 of the IB Oden with a Kongsberg $12 \mathrm{kHz}$ EM122 $1^{\circ} \mathrm{x} 1^{\circ}$ multibeam echo-sounder producing 432 beams per ping, and gridded at a minimum $20 \mathrm{~m}$ x $20 \mathrm{~m}$ grid cell size ${ }^{28,32}$. Imported into ArcMap 10.0, iceberg-keel ploughmarks were identified by a manual method. From the maximum visible length of each feature, controlled by iceberg-keel ploughmark cross-cutting relationships and maximum data extents, the orientation with respect to true north was determined. Initially, iceberg drift was assumed to be occurring in either direction along an iceberg-keel ploughmark (Fig. 1g), unless a plough ridge $\mathrm{e}^{25}$ or grounding $\mathrm{pit}^{33}$ was observed at the downstream end, thereby limiting iceberg drift to a single direction. Cross-sectional profiles (Fig. 2) were extracted perpendicular to the longprofile of each iceberg-keel ploughmark at an approximately mid-length distance (e.g. Fig. 2a) in IVS Fledermaus, and classification was applied to describe each ploughmark as either single-keeled or multi-keeled (more than one central incision) in form. This sampling position is justified, because most large-scale changes in iceberg-keel morphology as a result of grounding are expected to be rapid, and occur near the start of the ploughmark ${ }^{34}$. From these profiles, width and incision depth were measured from berm crest to berm crest, and from the sea-floor datum to the deepest part of the incision, respectively. Width/depth ratios were calculated from the division of width and incision depth, and the UV index was identified using the methods in ref 35 and a General Power Law $\left({ }^{\mathrm{G}} \mathrm{P}_{\mathrm{L}}\right)$ program ${ }^{35}$, which quantifies the shape of a profile with respect to the general power law equation. UV indices of 1 and 2 are representative of perfect $\mathrm{v}$-shaped and $\mathrm{u}$-shaped cross-sectional shapes, respectively ${ }^{35,36}$.

An iceberg floating hydrostatically with an aspect ratio $\varepsilon=\mathrm{W} / \mathrm{H}$, where $\mathrm{W}$ is the iceberg width and $\mathrm{H}$ is the iceberg thickness (accounting for subaerial and subaqueous portions; Extended Data Figure 5), will not capsize unless it is first able to overcome some energy barrier determined by the critical aspect ratio $\left(\varepsilon_{\mathrm{c}} \approx 0.75 \text {; equation } 1\right)^{37,38}$. Thus, for icebergs with maximum drafts of $848 \mathrm{~m}$ (equating to a total thickness (H) of $949 \mathrm{~m}$ ), a minimum width of $712 \mathrm{~m}$ would favour metastable conditions, and therefore prevent spontaneous capsize.

$$
\left.\varepsilon_{\mathrm{c}}=\sqrt{6 \frac{\rho_{\mathrm{i}}}{\rho_{\mathrm{w}}}\left(1-\frac{\rho_{\mathrm{i}}}{\rho_{\mathrm{w}}}\right)} \quad \text { (equation } 1\right)
$$

Here, $\rho_{\mathrm{i}}$ is the meteoric density of ice $\left(917 \mathrm{~kg} \mathrm{~m}^{-3}\right)$ and $\rho_{\mathrm{w}}$ is the density of seawater $\left(1,027 \mathrm{~kg} \mathrm{~m}^{-3}\right)^{37}$. If this $949 \mathrm{~m}$ iceberg thickness is instead considered to be an iceberg's width or length, metastable conditions would be present provided $\mathrm{H}$ does not exceed $1,265 \mathrm{~m}(\varepsilon \approx 0.75)$. If $\mathrm{H}$ exceeds this 
thickness, the iceberg will capsize spontaneously without any external energy input ${ }^{37}$. If icebergs with $\mathrm{H}=1,265 \mathrm{~m}$ are assumed to floating hydrostatically, this would imply a keel depth of $1,130 \mathrm{~m}$ which, given the bathymetry of Pine Island Bay, is only possible in a limited region seaward of this study's area (Extended Data Figure 2); otherwise the iceberg would be grounded on the seafloor. However, no iceberg-keel ploughmarks have been reported at water depths greater than those identified here from anywhere in the region. In addition, a keel-depth of $1,130 \mathrm{~m}$ is almost twice as large as icebergs calved from the Pine Island Ice Shelf today ${ }^{27}$.

An iceberg $949 \mathrm{~m}$ in length or width and less than 1,265 $\mathrm{m}$ in thickness must first be rotated, most likely by an external agent, in order to overcome an energy barrier and capsize ${ }^{37}$. As laboratory studies note, icebergs with $\varepsilon$ close to 0.75 need only rotate through a limited angle to induce iceberg instability (and cause capsize); however, as the iceberg thickness decreases (thereby increasing $\varepsilon$ ), the angle of rotation required increases (Extended Data Figure 6) ${ }^{37}$. For example, from the computations of ref 37 , an iceberg with $\mathrm{H}=1,000 \mathrm{~m}$ and $\mathrm{W}=949 \mathrm{~m}$ must first be rotated $14.9^{\circ}$ about its centre of mass before it will capsize (Extended Data Figure 6). For an iceberg with H = 949 $\mathrm{m}$ and $\mathrm{W}=949 \mathrm{~m}$ to capsize, it must be rotated $17.8^{\circ}$ about its centre of mass (Extended Data Figure 6). As in the original laboratory studies, both these examples assume iceberg length exceeds the iceberg width, to restrict iceberg capsize to the $\mathrm{x}-\mathrm{z}$ plane ${ }^{37}$. In this regard, icebergs with large aspect ratios are inherently stable, as noted by both modelling and observational studies (e.g. Extended Data Figure 7), and would require significant inputs of energy from external agents to capsize.

Today, Pine Island and Thwaites ice streams both present a characteristic crevasse spacing on the order of $1 \mathrm{~km}$ (Extended Data Figure 3) or multiples thereof (Extended Data Figure 7), resulting from the flow and deformation history of ice before it reaches the calving line $\mathrm{e}^{39,40}$. This inherent crevasse pattern will most likely dominate over the local stress distribution in determining the calving distribution. Moreover, bending stresses would probably exploit these pre-existing faults and fractures, rather than generate new ones ${ }^{41}$. Indeed, icebergs with along-ice-flow widths of $\sim 1$ km calved from the Pine Island Ice Shelf in January 2017 (Extended Data Figure 7), and proceeded to drift away from the calving margin into the Amundsen Sea without capsizing. Thus, whilst we have no way to resolve the crevasse spacing on Pine Island-Thwaites Ice Stream in the distant past, a crevasse spacing comparable to that observed today, coupled with the results of this study, would imply the calving of icebergs roughly as wide as they are deep, with a resulting high degree of metastability $\left(\varepsilon \approx 1.00>\varepsilon_{\mathrm{c}} \approx 0.75\right)$. 


\section{Data Availability Statement.}

Bathymetric data of Pine Island Bay analysed during the current study are available from the Bolin Centre for Climate Research, Stockholm University (http://oden.geo.su.se/oso0910). A shapefile of mapped iceberg-keel ploughmarks generated during the current study, and bathymetric data used in Fig. 2d, are available from the corresponding author on reasonable request. Bathymetric data used in Extended Data Figure 2 are available from the Lamont Marine Geoscience Data System (http://www.marine-geo.org/index.php).

32. Jakobsson, M. et al. Ice sheet retreat dynamics inferred from glacial morphology of the central Pine Island Bay Trough, West Antarctica. Quat. Sci. Rev. 38, 1-10 (2012).

33. Duncan, C. S. \& Goff, J. A. Relict iceberg keel marks on the New Jersey outer shelf, southern Hudson apron. Geology 29, 411-414 (2001).

34. Woodworth-Lynas, C. M. T., Josenhans, H. W., Barrie, J. V., Lewis, C. F. M. \& Parrott, D. R. The physical processes of seabed disturbance during iceberg grounding and scouring. Cont. Shelf Res. 11, 939-961 (1991).

35. Gales, J. A., Larter, R. D., Mitchell, N. C. \& Dowdeswell, J. A. Geomorphic signature of Antarctic submarine gullies: Implications for continental slope processes. Mar. Geol. 337, 112-124 (2013).

36. Pattyn, F. \& Van Huele, W. Power law or power flaw? Earth Surf. Process. Landforms 23, 761-767 (1998).

37. Burton, J. C. et al. Laboratory investigations of iceberg capsize dynamics, energy dissipation and tsunamigenesis. J. Geophys. Res. Earth Surf. 117, doi: 10.1029/2011JF002055 (2012).

38. Burton, J. C., Cathles, L. Mac \& Wilder, W. G. The role of cooperative iceberg capsize in ice-shelf disintegration. Ann. Glaciol. 54, 84-90 (2013).

39. Hughes, T. J. West Antarctic Ice Streams. Rev. Geophys. Sp. Phys. 15, 1-46 (1977).

40. Hughes, T. J. On the Disintegration of Ice Shelves: The Role of Fracture. J. Glaciol. 29, 98-117 (1983).

41. Benn, D. I., Warren, C. R. \& Mottram, R. H. Calving processes and the dynamics of calving glaciers. EarthScience Rev. 82, 143-179 (2007).

42. Nitsche, F. O. et al. Paleo ice flow and subglacial meltwater dynamics in Pine Island Bay, West Antarctica. Cryosph. 7, 249-262 (2013).

43. Fretwell, P. et al. Bedmap2: Improved ice bed, surface and thickness datasets for Antarctica. Cryosphere 7, 375-393 (2013).

44. NASA Earth Observatory. Glacial “aftershock” spawns Antarctic iceberg, https://earthobservatory.nasa.gov/IOTD/view.php?id=89638 (2017). 


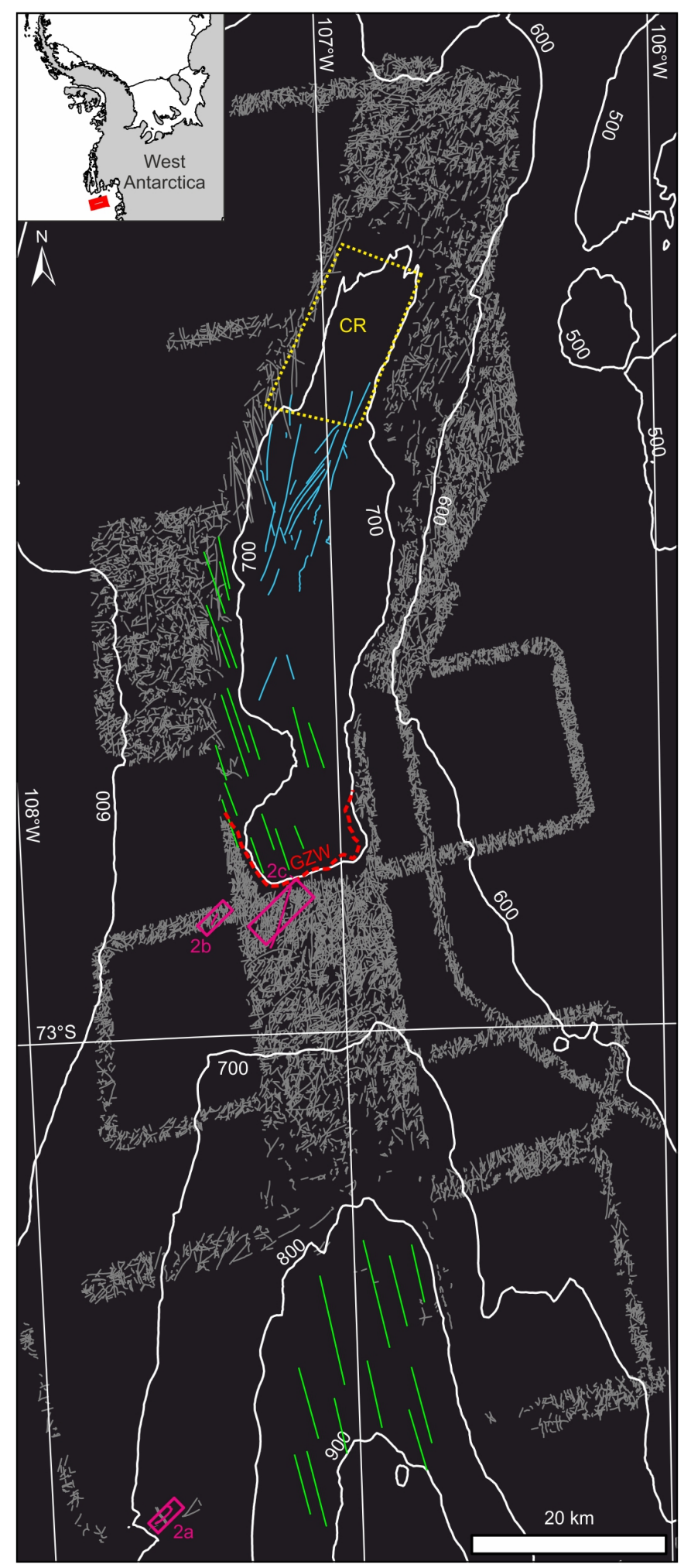

Extended Data Figure 1: Identified iceberg-keel ploughmarks within the study area. Map of iceberg-ploughmarks observed within the study area $(\mathrm{n}=10,831)$. The locations of iceberg-keel ploughmarks in Fig. 2a-c are highlighted in pink with figure bounds shown by a labelled pink outline. Iceberg-keel ploughmarks produced during an 'earlier' period of iceberg activity, seaward of a large GZW (the seaward limit of which is shown by a labelled dashed red line) ${ }^{28}$, are highlighted in blue $(n=30)$. Observations are limited by data extent and cross-cutting relationships. Inset shows the location of the study area. We note the observation of distinct sets of mega-scale glacial lineations directly seaward and landward of a large GZW, a number of which are outlined in green. The general area of corrugation ridges is shown by the dashed yellow outline and labelled CR. 

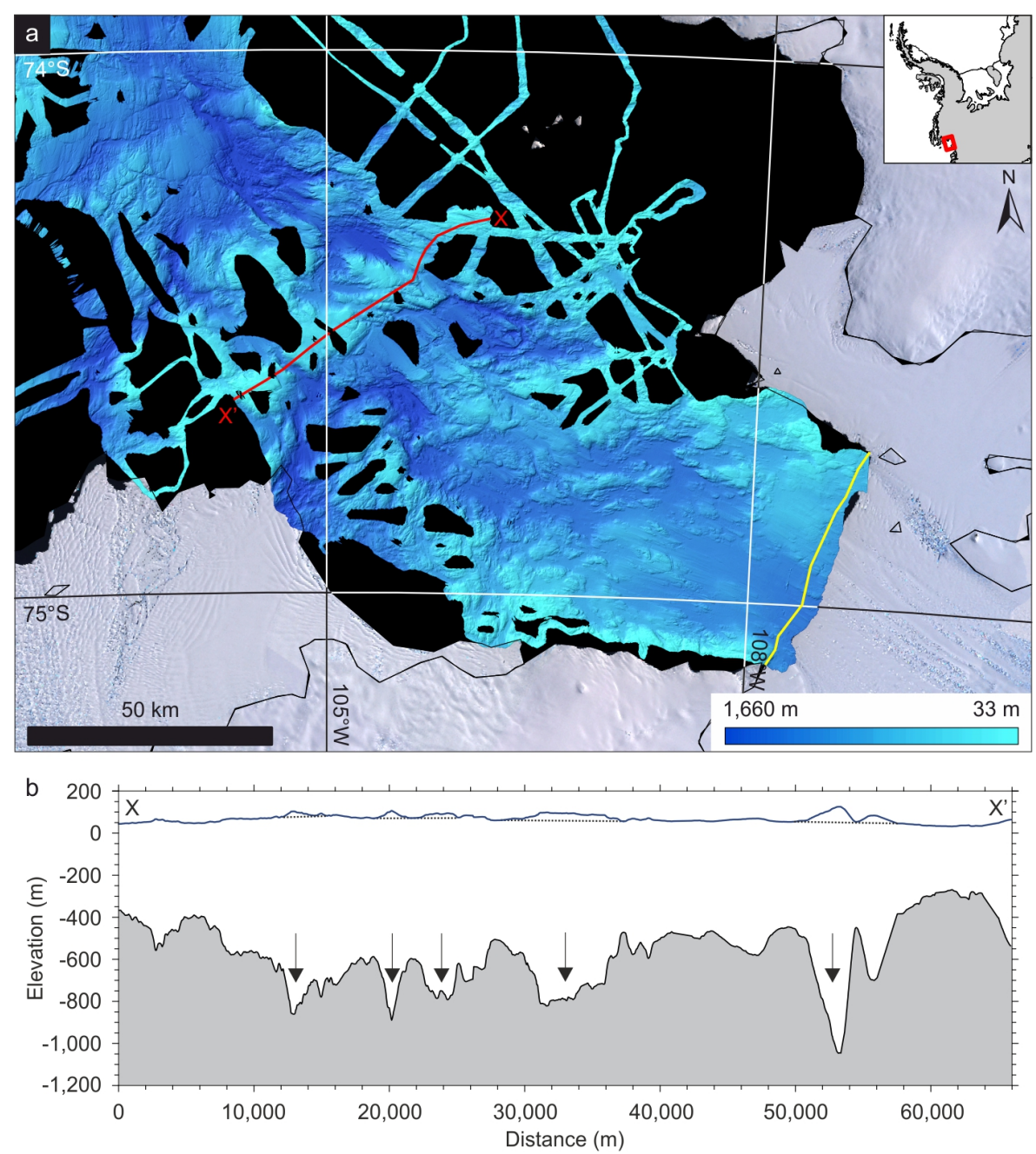

Extended Data Figure 2: Bathymetry of inner Pine Island Bay. a, Bathymetry of inner Pine Island Bay from ref 42 (grid-cell size of $35 \mathrm{~m}$ ). The Bedmap2-defined calving line is shown in yellow. b, Elevation profile of a prominent across-trough bathymetric ridge (red line), located $\sim 108 \mathrm{~km}$ from the Bedmap2-defined calving line ${ }^{43}$ (yellow line). Arrows show the location of isolated breaches, interpreted as cross-cutting channels. Blue line shows estimated ice freeboards, assuming ice was just grounded (in hydrostatic equilibrium) on ridge-surface and was meteoric in density $\left(917 \mathrm{~kg} \mathrm{~m}^{-3}\right)$. Dashed lines above breaches show interpolated ice freeboard, if an absence of grounding within the breach itself is assumed. 

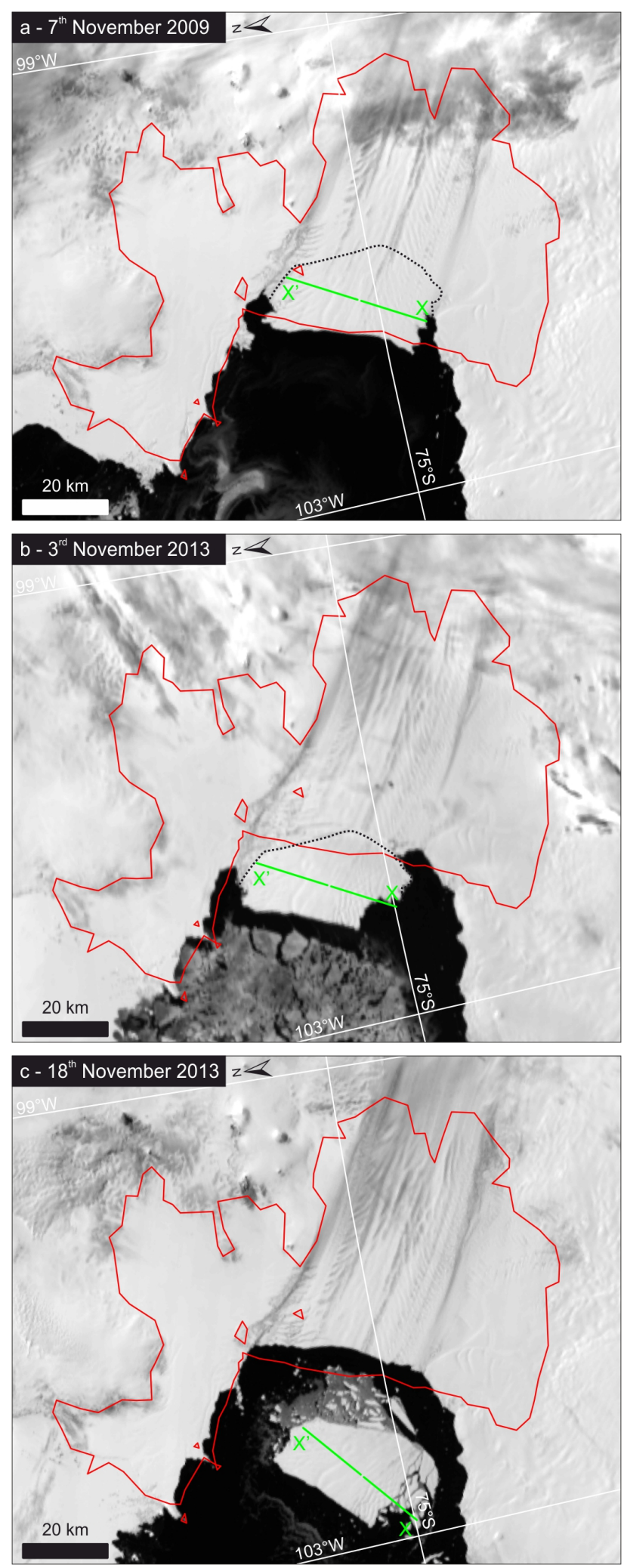

Extended Data Figure 3: Location of Icebridge transect analysed in Fig. 3b. Location of Icebridge ice-penetrating radar transect from flight DC8-100124 ( $7^{\text {th }}$ November 2009) analysed in Fig. 3b (green line, labelled x- $\left.x^{\prime}\right)$, overlain on NASA MODIS imagery dated $7^{\text {th }}$ November 2009 (a), $3^{\text {rd }}$ November 2013 (b), and $18^{\text {th }}$ November 2013 (c) available from the NSIDC ${ }^{31}$ (https://nsidc.org/data/iceshelves_images/index_modis.html). We note the positioning of this transect directly over tabular iceberg B31, which calved from Pine Island ice shelf on $13^{\text {th }}$ November 2013 . The black dashed line in panel $a$ and $b$ shows the landward-most extent of iceberg B31. The floating extent of Pine Island ice shelf as defined by Bedmap $2^{43}$ is shown in red. 


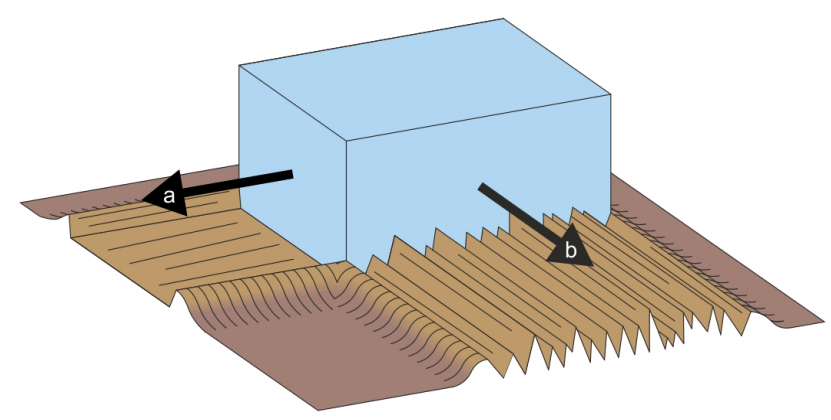

Extended Data Figure 4: Schematic of iceberg-keel ploughmarks expected to be produced by tabular icebergs. Wide, flat-bottomed iceberg-keel ploughmarks (a) will be produced if iceberg drift is approximately perpendicular to the rugged, ridge-channel underside morphology identified in Fig. 3b. By contrast, if iceberg drift is approximately parallel to the ridge-channel underside morphology, wide, multi-keeled iceberg ploughmarks with 'toothcomb-like' morphologies (b) will be produced. 


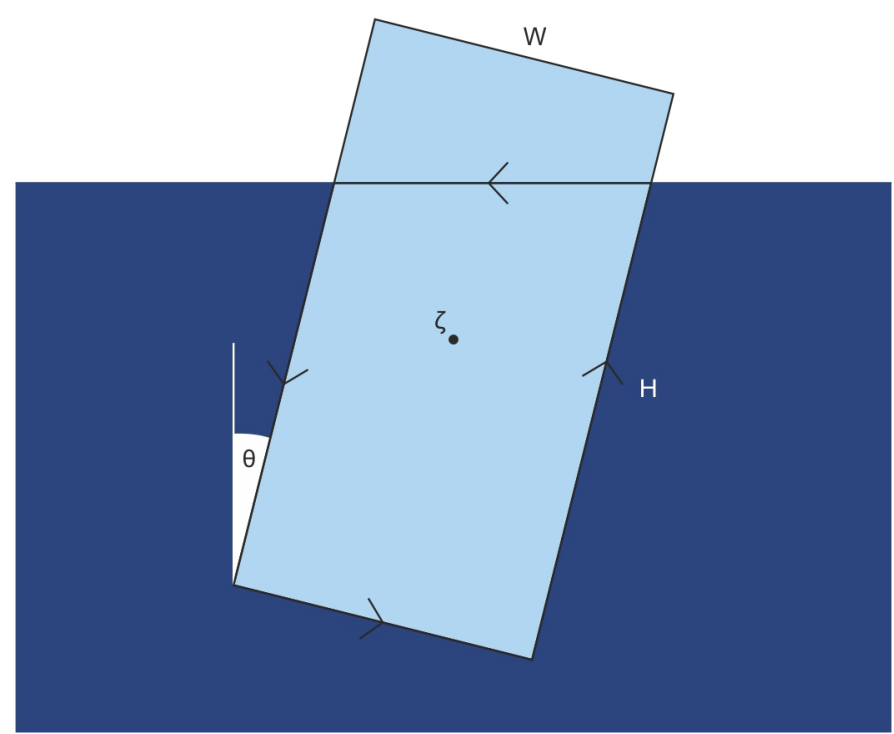

Extended Data Figure 5: Schematic illustration of iceberg cross-sectional dimensions needed to calculate an iceberg's gravitational potential energy and establish meta-stable conditions. $H=$ total iceberg thickness, $W=$ iceberg width, $\mathrm{CM}=$ centre of mass and $\theta=$ angle of rotation from an upright $(\mathrm{U})$ to a rotated position (R). The longest axis (L) extends into the page and is not shown here. Image adapted from ref. 37, American Geophysical Union. 


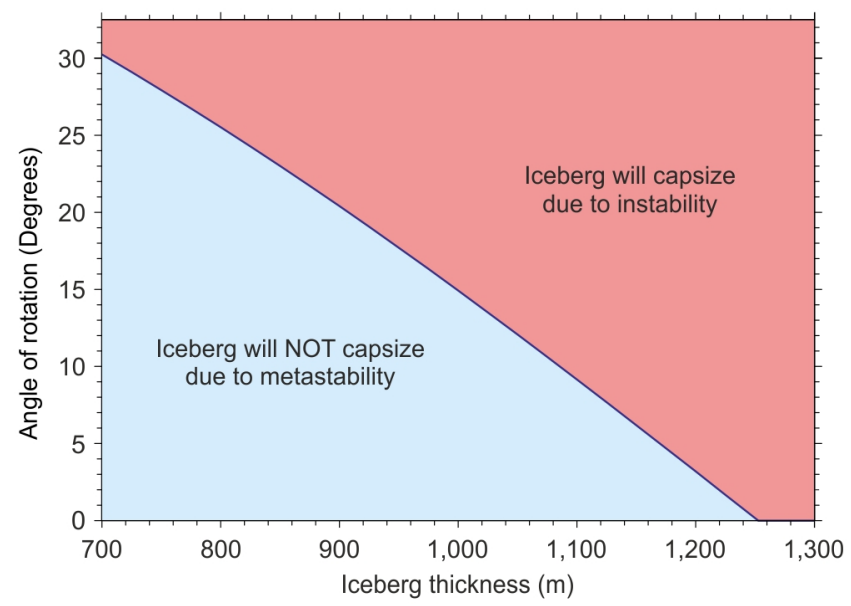

Extended Data Figure 6: The angle an iceberg $949 \mathrm{~m}$ in width (or length) and variable thickness (H) must be rotated by an external agent to overcome an energy barrier and capsize due to instability (blue curve). By capsizing, an iceberg width (or length) equaling 949 m could be transformed into a thickness of equal size. As iceberg thickness decreases, the iceberg becomes increasingly stable and requires a greater angle of rotation about its center of mass to develop unstable conditions that will cause the iceberg to capsize. Calculated from the computations of ref 37. 


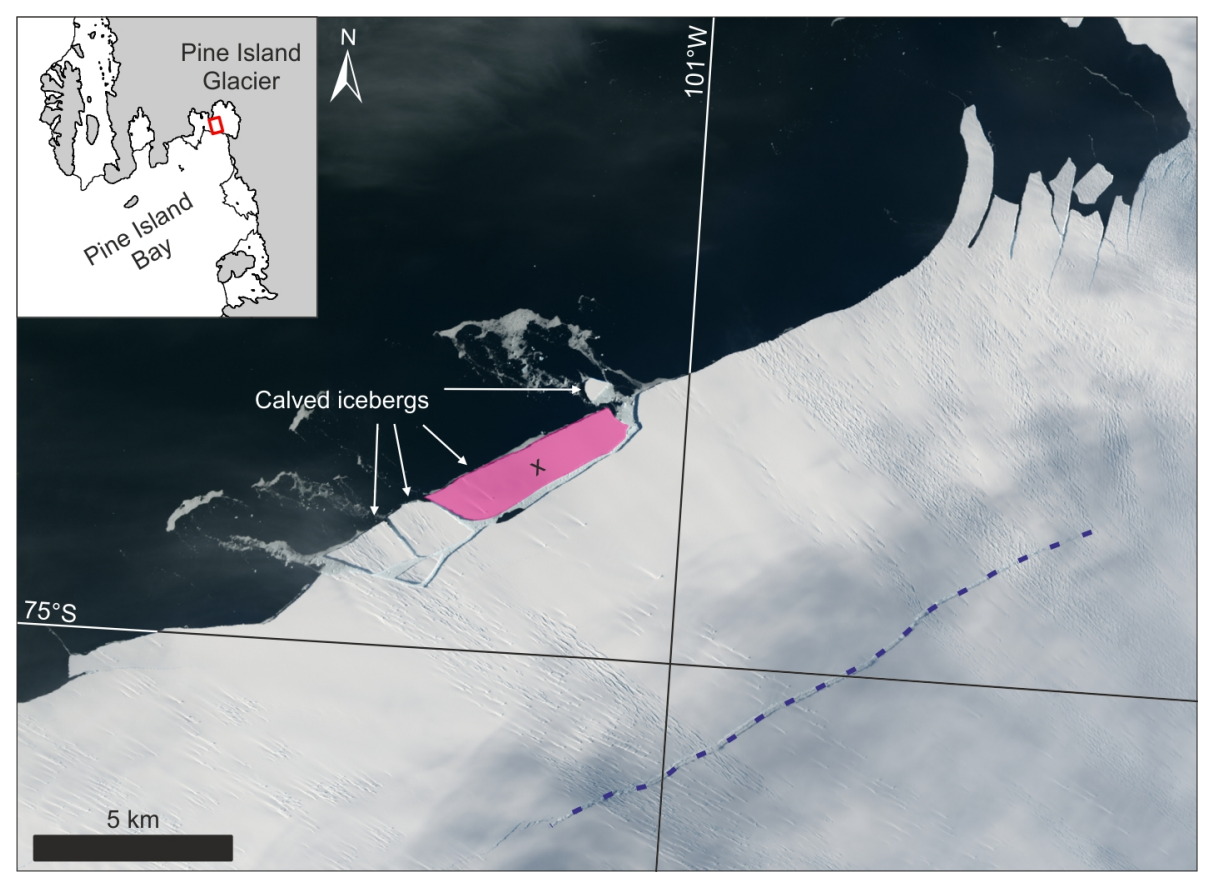

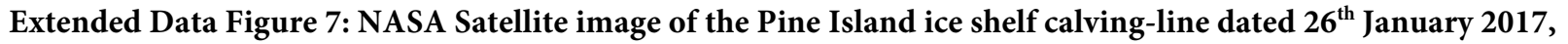
illustrating the typical planform morphology of icebergs (arrowed) calved during the period between the production of large tabular icebergs. Recording surface areas between $240,000 \mathrm{~m}^{2}$ to $5,200,000 \mathrm{~m}^{2}$, these icebergs are at most $<1 \%$ of the size of iceberg B31, which calved from the Pine Island ice shelf in November 2013. The largest iceberg (labelled ' $\mathrm{x}$ ' and shaded pink) measures $4,800 \mathrm{~m}$ by 1,050 m, in the across- and along-ice-flow direction, respectively. Dashed line overlying a prominent across-ice-flow rift shows the likely calving position of the next large, tabular iceberg. Image adapted from ref 44, NASA. 